\title{
SEEKING A GREATER IMPACT: NEW CHALLENGES FOR BUSINESS SCHOOLS
}

Jordi Canals 


\title{
SEEKING A GREATER IMPACT: NEW CHALLENGES FOR BUSINESS SCHOOLS
}

\author{
Jordi Canals ${ }^{1}$
}

\begin{abstract}
Business schools have made a very important contribution to management education over the past decades. The new economic and social context creates new challenges for them. Their capabilities will have to evolve if they want to have a deeper impact.
\end{abstract}

Keywords: Corporate governance.

${ }^{1}$ Professor of Economics, IESE 


\section{SEEKING A GREATER IMPACT: NEW CHALLENGES FOR BUSINESS SCHOOLS}

\section{Introduction}

Management was one of the greatest human innovations of the twentieth century. Previous centuries had seen major advances in scientific discovery in Europe and Asia, but the application of science and its impact on most people's lives had been limited. With very few exceptions, such as the printing press or the steam engine, which paved the way for the first and second industrial revolutions in the eighteenth and nineteenth centuries, most innovations and discoveries did not much affect the life of individuals and society.

The speed of discovery accelerated in the early twentieth century. At the same time, a true revolution was under way in the organization of industrial production in Europe and the United States, one that would allow those discoveries to have a wider impact: the emergence of the modern corporation - which shaped manufacturing and distribution - and of management, as a new profession needed to master the complexities of corporations. ${ }^{1}$ Together, the modern corporation and professional management opened the door to mass manufacturing and the application of scientific knowledge to the development of products and services that meet basic human needs in our societies, including automobiles, health care, electricity and communications.

Professional managers at the helm of these organizations contributed to their growth and development and also to their financial and strategic sustainability. Chief executives and senior managers gradually took over from the investors or entrepreneurs who had started the companies.

In the last century management became an important new profession. Its basic principles were applied to the essential functions of organization, marketing, finance, operations and people development in a more rigorous and systematic way. The growth of enterprise in the twentieth century and the global reach of many companies bear witness to the rise and social relevance of modern management.

\footnotetext{
${ }^{1}$ The emergence of the modern corporation in the twentieth century is described by Chandler (1990) in Scale and Scope. The rise of professional management is well documented by Chandler (1977) and Khurana (2007).
} 
Business schools were the academic domain in which the foundations of the management profession could be systematically learned and developed and research could be conducted into management problems and challenges. Wharton, set up in 1881 within the University of Pennsylvania, was the first business school to be founded in the United States. ${ }^{2}$ A few more graduate schools were founded in the United States in the period before the First World War, including Dartmouth, Harvard and Kellogg, but it was before and after the Second World War that they really flourished. In Europe most of the leading schools were founded in the late 1950s and 1960s.

Business schools are still very young institutions. All in all, by developing generations of managers they have had a positive impact on people, companies and society. Thousands of people around the world are enrolled in MBA programs and open, executive education programs. The positive effects of business school education on the lives of many people and on the success of many companies is widely acknowledged. The failures and mistakes of business school-educated managers and the firms that trusted them - including those brought to light by the 2007 financial crisis - cannot obscure the positive impact business schools have had in producing good professionals and, through them, fostering job creation, investment and innovation. This is particularly important in emerging countries such as Mexico, Brazil, India or China, where the growth of companies has gone hand in hand with growth in higher education and the number of students graduating from business schools.

In a relatively short time, leading business schools have become important paradigms of excellence in graduate education and many of them have globalized education as no other universities had done before. The many threats and opportunities facing organizations and society in the twenty-first century will keep the demand for professional managers and entrepreneurs very high and business schools will continue to play a decisive role in educating them and providing society with the managerial talent it needs in order to meet some of its most compelling challenges. It is true that business schools face major tasks and have some questions to answer, particularly regarding their contribution to the current financial crisis. They must also take a decisive hand in reshaping the notion and mission of the firm (looking beyond economic value creation) and rethinking the role of senior managers in organizations.

In this paper we briefly review the main drivers of business schools' success in the twentieth century (Section 2), along with some of the major problems they face today and things that need to be changed (Section 3). In the final section we explore and discuss the new challenges that business schools will have to tackle if they want to remain relevant institutions, including the reframing of the notion of the firm and the rediscovery of the role of senior managers.

\section{The Essential Model of Successful Business Schools in the Twentieth Century}

It can be argued that business schools became prosperous institutions because economic growth in the second half of the twentieth century was higher than in the past. This is partly true, but it can also be argued that economic and business growth in that period was partly driven by the professional managers used by so many companies. Some of those professional managers were educated at business schools and the knowledge and ideas developed in the schools had

\footnotetext{
${ }^{2}$ For a detailed account of the birth of the first business schools, see Khurana (2007). 
an impact on a wider circle of managers. One might conclude, therefore, that while economic growth was stimulated by technological development and demographics, there was another factor at work, namely management, which gave birth to a more efficient way of organizing the production and distribution of goods and services. Business schools contributed to this process by helping educate some of those managers. The contribution of business education to this process is apparent in advanced economies such as the United States, France, the Netherlands, Spain and the United Kingdom; and similar patterns can be seen in rapidly emerging economies such as China, Brazil or Mexico, where business schools play an extremely important role in fostering business education and entrepreneurship.

Various different models of business schools emerged in the United States and, later, in Europe. The Harvard Business School, for example, from the time it was founded emphasized the desire to have an impact on the practice of management and the focus on a comprehensive general management, approach to the profession, an approach shared by Dartmouth and Kellogg. Other schools, such as Chicago, MIT, Stanford and Wharton, did not put so much emphasis on having an impact on management practice as on developing a rigorous body of knowledge around the different managerial functions that could be successfully applied to relevant business problems.

In Europe, INSEAD and London Business School, among others, concentrated initially on educating young students at the MBA level, while others, including IESE and IMD, put more effort into helping develop senior managers.

Irrespective of the different models they embodied, these and other schools based their models on certain key factors. The first was the creation and development of a full-time faculty made up of professionals with an academic qualification (mostly a doctoral degree) and some realworld business knowledge and experience. Faculty quality was key to designing good, solid programs and having a deep impact on students.

Faculty members also did research with the aim of creating or disseminating new knowledge in traditional disciplines such as marketing or operations, or new areas such as innovation or leadership. Faculty quality and rigorous programs were the essential drivers of good students, especially before and after the Second World War, when business schools were not yet well known and the programs they offered had no tradition in the field of higher education.

The quality of the students, the impact the programs had on them and the widespread adoption of ideas, concepts and models developed in business schools gradually created a demand among recruiting firms, initially more strongly in the United States than in Europe. Most alumni were very pleased with their business school experience and many were the first to "sell" the schools and their programs. ${ }^{3}$ Encouraged by alumni, many companies started to take advantage of the new programs either by hiring business school graduates or by sending senior executives on open, general management programs.

Eventually, the positive experience of alumni and companies alike was crucial to securing funding for endowments at some schools, particularly in the United States, which was an important factor in building financially sound educational institutions.

Under the influence of growing student numbers, the increasing impact of business schools' programs and faculty on many companies, new initiatives the schools launched and the

\footnotetext{
${ }^{3}$ This is still true today. See Holton and Inderrieden (2006) on MBA graduates' satisfaction.
} 
reputation they acquired, a number of very strong brands emerged, not only in management education but also in the wider field of higher education.

This model (see Figure 1) has been the linchpin of the success of many business schools in the United States and Europe in recent decades. Yet this successful model has created its own problems and the business context in which business school graduates must work has changed significantly. The financial crisis and the changing context have brought sharp criticism of business schools, calling their role into question. ${ }^{4}$ Business schools will therefore have to change if they want to continue to have a positive impact on people, firms and society.

\section{Figure 1}

Business schools: A successful model

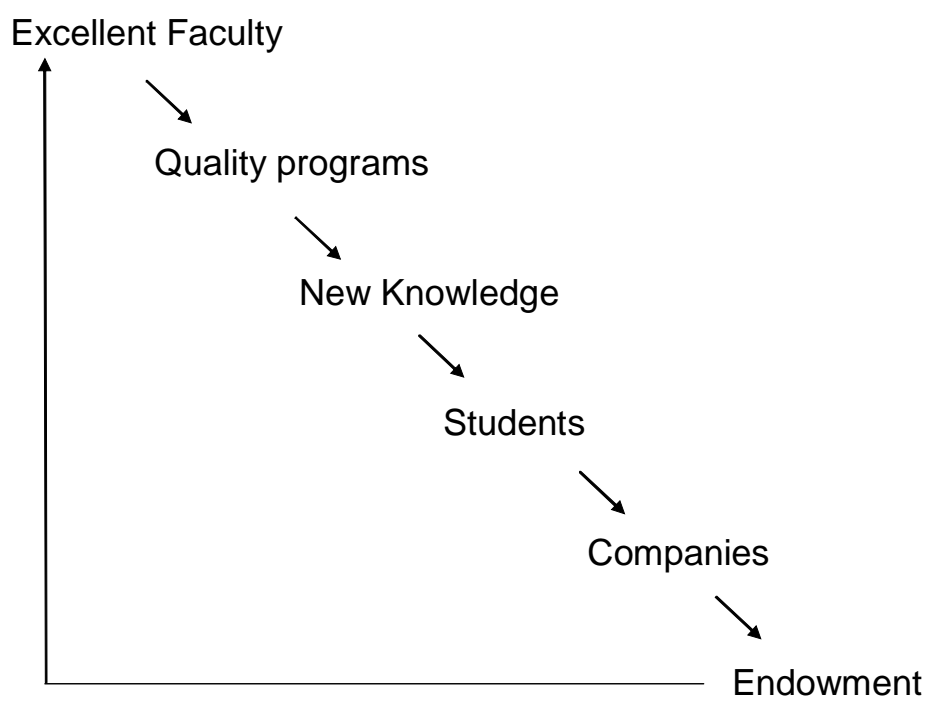

\section{A Model in Crisis?}

Business schools have been widely criticized in the past few years, especially in relation to the dotcom bubble (and ensuing market crash), corporate scandals and the current financial crisis. Analyzing the criticisms, we can distinguish two categories of observations. The first relates to factors external to business schools, mainly the financial crisis, globalization, the notion of the firm and the reputation of business. The second category has to do with certain internal gaps or deficits in business schools themselves.

\subsection{External Factors}

The role of business schools. As happened with the dotcom crisis at the end of the $20^{\text {th }}$ century, some observers accuse business schools of having a hand in the unfolding of the current

\footnotetext{
${ }^{4}$ Among others, see Pfeffer and Fong (2002), Mintzberg (2004) and Collins and O'Toole (2005). 
financial crisis. ${ }^{5}$ They have a point, as we will see, although for reasons other than those usually given, such as the collapse of the banking system in the United States, basically because investment banking was not the most important industry for most business schools and MBA graduates were not the most important source of young talent for investment banks.

It is true that many MBA graduates went to work on Wall Street, but the total number of MBA graduates in significant managerial positions in investment banking companies was relatively small even in the case of schools for which investment banking was the most important recruiting industry; and their responsibility was probably similar to that of other managers who had not been to business school. There were other professionals with major responsibilities in those firms, including accountants, lawyers and financial analysts; and there were regulators whose job was to supervise them. For most investment banks, moreover, graduate business schools were not the most important suppliers of talent, as the total number of students was small compared to the numbers coming out of undergraduate schools in a wide range of disciplines, including mathematics and physics.

Whether schools and their programs could have provided better frameworks of business and ethics, and a better integration of the two; or whether senior managers with a good business school education could have done more to prevent the implosion of investment banking; or more importantly, whether, given a better education, those graduates could have set a better example of professionalism and integrity; that is a different question. Because their programs are so influential, business schools (and their graduates) have a special responsibility to set the highest professional and ethical standards in the corporate world.

Globalization. Globalization and its impact on the business world is another area of concern (Ghemawat, 2007). Many Western companies have failed in their efforts to become more international or global. Some have made major mistakes in their efforts to penetrate foreign markets. Many more have had cultural problems when working in foreign environments. Developing and transferring talent in global companies has become a nightmare. Business schools have not done a good enough job of making the case for globalization and clarifying the specific need for it and the variety of dimensions, experiences and human and cultural values to be explicitly taken into account. However, the international growth of firms is still a recent phenomenon about which there is a lack of empirical evidence covering a long enough time period. Business schools need to do a better job of understanding it, teaching it and, more importantly, practicing it in their programs and activities. There is no denying that business schools have a long way to go in terms of taking globalization more seriously.

Corporate crisis. The third relevant factor is the serious damage inflicted on firms' reputation over the past decade. In many countries, companies used to be admired institutions that created jobs, generated investment and were drivers of progress. Business leaders, be they board members, CEOs or senior managers, were admired professionals who put their skills and capabilities at the service of companies.

Unfortunately, perceptions have changed over the past twenty years. Corporate crises have erupted, companies have suffered severe blows to their reputation and many firms, not just investment banks and other financial institutions, are now seen as pure profit maximizers, with

\footnotetext{
${ }^{5}$ The causes and actors in the unfolding of the financial crisis are too complex and the blame cannot be pinned to a few individuals. McDonald's (2009) account of the Lehman Brothers bankcruptcy and Tett's (2009) description of the change in strategy at JP Morgan help explain the complexities and nuances of the banking crisis.
} 
the result that their role in society has come into question. At the same time, some business leaders are now seen as the villains of the piece and as having either driven these events or allowed them to happen. Public opinion sees them as opportunists with a short-term focus on their own benefits and privileges, and holds them responsible for many of today's corporate disasters.

These are important issues for society. Business schools, many of them still clinging to the traditional financial-based models of management, have been very slow to react to these challenges and integrate ethics across the curriculum. As institutions whose mission is to educate managers and business leaders, business schools must rethink the role of companies in society, the job of business leaders and how to include these dimensions in their programs.

\subsection{Internal Factors}

Unfortunately, the challenges for business schools do not come only from the outside world. Their own development and success have sown the seeds of internal discord that need to be tackled. Areas in which many business schools show major deficits include mission, governance, faculty development, relevance, humanistic approach and funding. ${ }^{6}$

\section{The Mission Deficit}

Research has shown that organizations with a strong sense of mission are able to develop informal mechanisms that can lead to higher performance and increased work satisfaction. More importantly, a clear mission sends a signal to all members about why the organization exists, the values it stands for and its purpose. ${ }^{7}$

Even though a good deal of this research has been done by business school faculty, some business schools have no clear sense of mission or of the role they wish to play in society. Clearly, they all want to educate people and develop new knowledge. The question is, is this still valid today? And if it is, why do they want to do this? And what balance should there be between educating people and developing new knowledge? At the same time, having a clear mission helps to frame many strategic decisions, as the experience of schools as diverse as CEIBS, IAE, IPADE and IESE demonstrates. In principle, there is no best model, but it is still important for a business school to understand why it exists and what it wants to do. Every school has its own view, but it is good to make that view explicit and connect it with the school's strategy, faculty development, program design and research initiatives. ${ }^{8}$

\section{The Governance Deficit}

Academic institutions in general have a poor track record in governance. There are many possible explanations, but the lack of professionalism in their management (very often

\footnotetext{
${ }^{6}$ Lorange (2008) and Thomas (2007), among others, have described other important challenges that business schools face today.

${ }^{7}$ The concept of the firm's mission has a long history. Sometimes under other names (such as corporate "purpose"), it has been recognized in management research as an important linchpin of great firms. See, among others, Barnard (1938), Selznick (1957), Drucker (1974) and Collins and Porras (1996).

${ }^{8}$ For instance, since its foundation in 1958 IESE's mission has been to help develop leaders who wish to have a deep and positive impact on colleagues, firms and society at large, through professionalism, integrity and spirit of service.
} 
academics with no particular leadership skills are in charge) and the powerful voice and influence of senior faculty are important factors.

Business schools are influential institutions. As such, their governance matters a great deal. There are several levels of governance to be considered in business schools. The first is the relationship between the parent university and the business school, which very often can result in lack of strategic and financial autonomy.

The second is the accountability and powers of the dean and senior faculty. There is no single best model here, but it is certainly an issue that is not always well defined in business schools.

The third is the role of faculty in designing programs, shaping research initiatives, promoting faculty to tenured positions and shaping the strategy of the school. Good governance needs to give faculty an appropriate role in business schools, one that does not block change. Finally, the role of alumni and advisory boards also needs to be defined in the governance model.

\section{The Faculty Development Deficit}

It is well known that a faculty crunch is coming for many business schools. In informal discussions among business school deans and administrators there is a view that there may not be enough $\mathrm{PhD}$ graduates to replace the senior faculty due to retire from top business schools over the next two decades. Faculty growth for new projects is a major challenge. And the deficit looks even bigger when one considers how to develop the kind of faculty needed to best achieve a business school's mission.

In many business schools, faculty development seems to be left to take place spontaneously. For some faculty members this may work; for others it does not. Worst of all, it leads to a waste of time, resources and human aspirations that can be devastating for students, scholars and schools. Leaving faculty development to the entrepreneurial initiative of individual faculty members is the equivalent of neglecting the role of coaching in any major team sport or in an orchestra, or the role of residency training for young medical doctors.

The faculty crunch is there, but schools could manage it much better if they fostered a virtuous process by which the talents of each individual are used more productively from the very beginning.

\section{The Relevance Deficit}

The relevance challenge affects both educational programs and research. After the Second World War business schools became relevant institutions because they helped tackle a very important need: the education of professional managers and the development of a body of knowledge in the main management disciplines. In the 1970s and '80s, many business schools became more interested in promoting a type of research similar to that of other social science schools. ${ }^{9}$ Despite its claim to superior academic rigor, research became increasingly irrelevant to management practice.

The relevance deficit also became very clear in schools' programs. Many top United States business schools did not offer executive programs until very recently. This was partly a matter

\footnotetext{
${ }^{9}$ The struggle to become a social science discipline is well documented by Khurana (2007).
} 
of choice; but it was also attributable to faculty members' lack of interest in working with senior executives on real business problems.

My hypothesis is that the risk of irrelevance in research, which is the most frequently mentioned problem when discussing relevance, is less when faculty members have to work with senior executives in the classroom. Working with experienced managers stretches faculty capabilities and expertise and makes them more aware of real corporate problems. Not every school has to do it the same way or to the same extent, but such engagement is a clear signal of how relevant to the real world a school wants to be.

\section{The Humanistic Deficit}

The aspiration to make management a more solid, science-based profession had another unintended effect: it led to the adoption of an economics-based model of the firm as an abstract organization whose social purpose is to make very efficient use of resources and maximize shareholder value. ${ }^{10}$ In this model, senior managers are agents whose functions are delegated by the principals (shareholders).

In the early stages of capitalism, in the eighteenth and nineteenth centuries, the business world was certainly not as rosy as some optimists would like to believe. At the beginning of the twentieth century, however, prominent business people realized that companies had a social purpose beyond that of making money. In fact, the creation of schools to train managers, such as Harvard, Dartmouth or IESE, and the willingness of major donors to support their efforts was evidence of a conviction that rigorous, ethical management education was important for the good of society.

Unfortunately, certain management and financial theories and the more prominent role of capital markets as drivers of modern capitalism have displaced some of those early ideals. The force of pragmatism in getting results, irrespective of what happens to the individuals working in the organization, has become the dominant paradigm in the practice of management. ${ }^{11}$

As a result, organizations have become more impersonal and individuals are often treated as just another resource, causing employee loyalty to evaporate. Yet companies depend on and consist of people, so the claim that people are important is stronger than ever. Despite this, many decisions are taken without consideration of their impact on people and companies. Our management models are completely void of the human presence; decision making is mechanical and financial incentives shape people's motivations. Even so, this approach is weak, as the underlying model of human behavior is weak and relies almost exclusively on economic incentives.

Business schools have contributed to the spread of this view by underplaying the role of individuals in organizations and business decisions. New research paradigms have been built around models in which human beings and their qualities are either absent or are manipulated by assumptions that do not fit with the way people behave in the real world. This is an area that needs serious improvement and business schools should take up this responsibility.

\footnotetext{
${ }^{10}$ Roberts (2004) presents a good summary of this view of the firm.

${ }^{11}$ Ghoshal (2005) argues forcefully about the negative impact of bad theories on management and the life of corporations.
}

8 - IESE Business School-University of Navarra 


\section{The Financial Deficit}

In the race to build the best possible schools and the most gifted faculty, business schools have paid higher salaries to their professors. Faculty financial compensation in business schools is already higher than in most professional schools. Many schools have cut faculty's teaching workload, in some cases turning teaching into an irrelevant sideline, in order to increase their research output. At the same time, business schools have been trying to attract top students with better scholarships. These factors, combined with higher investments in technology and other physical assets, have put schools under financial pressure.

In the United States, business schools used to rely on their endowment to pay higher salaries and attract students, and were less dependent on academic fees. In Europe, schools had to be closer to the real world and offered more executive education. In both cases, there is a problem. For United States business schools the endowment model is good when stock prices go up, but it becomes a nightmare when market prices fall steeply. For European business schools executive education is a great activity for many reasons, but some do it only for financial gain, which is not the best motivator in the long term.

The challenge for business schools is to develop an economic model that will make them sustainable in the long term. There is no one recipe; each school must design its own model. Their development will be a test of how well they are run.

\section{Areas Business Schools Need to Think About}

In light of the current financial crisis and its impact on corporate reputation, a more solid and comprehensive notion of the firm and a positive view of the role of business leaders seem indispensable for schools that aspire to develop business leaders through educational programs. Promoting such notions and ideas will help business schools remake their role in society.

There are other areas, too, where business schools need additional work. Companies, recruiters and executives expect this. We have referred to some of them in section 2 in this paper. We would like to highlight some that have been neglected and are more difficult to tackle: integration, globalization, model of leadership development, relevance, life-long learning and organizational architecture.

\subsection{Reframing the Notion of the Firm}

The first external challenge that business schools must tackle is how they can contribute to a reframing of the notion and purpose of the firm in society and what the role of business leaders should be. This is a priority because business schools need healthy companies with a clear purpose if they want to have a positive impact on them. If companies do not enjoy a high reputation in society, business schools are likely to become less relevant and to encounter serious difficulties in attracting outstanding faculty, top firms and excellent students.

We define a firm as an organization, made up of people who work together for the purpose of producing goods and services for customers, creating economic and social value in the process, as well as opportunities for professional and personal development. 
This definition could be a good starting point for reframing the role of firms in society and how business schools think about firms. In fact, this perspective goes beyond the current financial view of the firm and calls for reflection on the following aspects.

\subsubsection{Profit Maximization}

Over the past few decades the dominant view of the firm has been financial. Borrowing from a tradition developed in economics, firms have been seen as profit maximizers. There has been a confusion here; most prominent economists never said that profit maximization was the only goal a firm should pursue. ${ }^{12}$ In their effort to build a theory they simply chose a working hypothesis, namely that firms are profit maximizers in the same way as consumers are utility maximizers. However, it is not difficult to see that even if conscious consumers try to be utility maximizers, there are many other dimensions to their lives that make them behave sometimes in ways where utility maximization is not the only driver nor economic results the only outcomes.

Similarly, companies are supposed to maximize shareholder value. Yet this is neither the only goal companies have nor one that could be achieved by purely economic means, and this for several reasons. The first is that companies are groups - communities - of people, working together, learning together, in order to serve customers' real needs in an efficient way. Profits are one indicator of how well a company is doing, but not the only one. At a more personal level, people like to get things done in the best possible way, which means they have to work with others and cooperate with them to make things happen. Trust is essential to such relationships. People want workmates they feel at ease with, or that they can learn from, or that they can communicate with, in the confidence that the others will not behave opportunistically (Andreu, 2009). Corporate cultures and values that foster such a work environment should be a priority for top managers, ${ }^{13}$ whereas incentives that destroy trust and the necessary basic attitudes should be removed from firms' policies, even at the cost of a short-term impact on profits.

From an action viewpoint, profits are the outcome of thousands of decisions, both on the revenue side and on the expenses side. Those decisions are taken by diverse people in organizations whose main goal may not be to maximize profits but simply to do good things. Nobody knows, in the real world, what maximizing profits actually means or what a firm's maximum profit could be. Good professionals at all levels in any reasonable organization strive to work well, be effective and make a valuable contribution to the firm. So, let's say that profits are the outcome of a complex process driven by the commitment and behavior of many individuals. To ensure a good outcome, that process and people's motivations must be good. This means, among other things, that people must be good professionals, work well, be entrepreneurial, interact reasonably well with one another, take care of the needs of the people they work with, have a good level of motivation, listen to others, serve customers and employees as they would like to be served, keep their promises and commitments, be accountable and invest in continuous learning.

\footnotetext{
${ }^{12}$ Nevertheless, the economics language has been very influential in shaping this dominant view of companies. See Ferraro, Pfeffer, and Sutton (2005).

${ }^{13}$ See Rosanas (2008) for a fuller discussion of this view. 
The focus, therefore, both in theory building and in teaching and learning about management and leadership, must be on the process by which profits are generated and how that process - and the people involved in it - can be improved. In a nutshell, good leadership is about results and how the people involved in the process of producing results - employees, customers, shareholders, etc. - learn through it and how their contributions and ideas are taken into account.

\subsubsection{Firms and Customers}

A key dimension to be considered is how a firm and its senior managers understand their primary function in society, namely to serve customers. Making money comes second. If a firm does not add real value to customers, its economic and commercial success will be fickle, even though it may make a profit in the short term. Making money is not the same as creating and building a firm. Again, in theory building and management learning there is insufficient emphasis on how well companies must do when serving their customers. This is something professors tend to leave to Marketing courses, which is a huge mistake, as it is the first source of social legitimacy for companies, the first outcome to be achieved and the driver of future profitability.

\subsubsection{People in Organizations: A Humanistic View of the Firm}

The dominant economic and sociological paradigms in management have given rise to a simplified notion of people in organizations. In both the economic and the sociological approach the notion of individual freedom is replaced by determinism, i.e. given the right incentives or the right environment, people will always behave in a certain way, while the role of incentives is to shape human behavior to serve organizations' goal of maximizing profits.

This assumption is at odds with one of the basic tenets of more humanistically informed companies and management scholars, which is that people do matter. Some companies refer to people as their most important asset or pillar. Innovation and creativity, so badly needed today, depend on the talent, commitment and willingness of people. Unfortunately, many managerial models across different disciplines - including finance, marketing and organizational theory take a frankly ludicrous view of people in organizations.

The humanistic approach to management also has some fundamental pillars. The first is that each person is unique and can make a unique contribution. Second, each person has an intrinsic dignity and basic rights, which must be respected in the workplace and in society. Third, each person is born free, has the freedom to make decisions and the right not to be coerced to use his freedom against his own will. Fourth, each person is responsible for the use of his capabilities and rights and accountable to others for his external actions and the performance of his duties. Fifth, each person has basic material needs, but also aspirations and motivations that go beyond material or economic incentives, and cannot be "bought". Sixth, each person has values, which must be respected so long as they do not entail harm to others.

Organizations that wish to be respectful towards people must take these qualities into account. Similarly, senior managers, in their decision making, should also consider certain basic principles. First, try to do as much good as possible to the people working in the firm and not harm them. Second, recognize in all relevant ways each person's contribution to the firm. Third, respect people's ideas, values and beliefs. Fourth, give them challenges and opportunities to develop their capabilities and skills; good leaders must also be demanding, in a gentle way. 
Fifth, invest in their education and development. Sixth, help create a context in which human aspirations can be at least partially fulfilled. Seventh, foster a climate of trust.

Over the past decades many theories have assumed that management was neutral. Yet management is not neutral; it involves people making decisions and being influenced by their own and other people's decisions, based on choices and values. To isolate the decision making process as a purely rational process is unrealistic. Managers should bring values to their work. To make this sustainable and avoid clashes among people with different values there is a condition that must be met: each person must respect the other as a unique human being with an intrinsic dignity that deserves respect, and each person's values must recognize this very simple fact.

\subsubsection{Firms, People and Learning}

There are several reasons why, when designing, producing and delivering goods and services for their customers, the people who work in companies must have opportunities to learn. The first is that, in any profession, learning and improvement are the result of getting things get done. Medical doctors learn by seeing and advising patients, engineers by designing and testing new mechanisms to solve physical problems, and so on. At all levels in organizations, people learn by doing, especially with others. The modern organization is essentially a team effort. Individuals learn from others' skills, knowledge and attitudes. A good company that wants to serve its customers better every day must foster a positive spirit of learning and improvement. Learning can also be negative: people learn to behave badly, or how to make the least effort and hide it. Top managers must see to it that the learning process is positive and helps to improve the firm's ability to serve customers better.

The second point about learning is that it matters to professionals in search of challenging professional opportunities. Money matters to them, too, but as their basic needs are met, they look for opportunities to learn and improve their capabilities in order eventually to make a real difference. In an era where talent is scarce this dimension is more relevant than ever. Economic compensation is basic, but companies need to ensure that employees also find attractive professional learning opportunities in their work, serving customers.

\subsubsection{Companies and Society: The Search for the Common Good}

Companies are important institutions in society. They create jobs, invest, innovate, train people, help use scarce resources effectively and, in various ways, play an important role in modern society. Firms' distinctive mission, of course, is to serve clients well and, in doing so, generate economic value. At the same time, however, they cannot afford to neglect either their internal mission (developing their own people) or the society in which they operate. Our societies are increasingly complex and are facing new problems and challenges: education, globalization, immigration, public infrastructure, innovation, research, sustainability and so on. None of these challenges belong to any one company in particular, of course. But all companies help to create what the classical philosophers called the common good, that is to say, the good that is needed in any society in order that individual goods may be achieved.

Some of the problems and challenges just mentioned are the responsibility of governments, but neither primarily nor exclusively. Indeed, the principle of subsidiarity requires that governments not interfere in areas where the private sector could do the job better. Civil society and companies therefore also bear a share of the responsibility for improving the common good 
of the society to which they belong. Societies need educated people, virtuous citizens, professional opportunities and a good deal of innovation and dynamism. Firms are capable of doing a great job in all those areas, thus making a valuable contribution to the common good. Clearly, what we are talking about here is not philanthropy, which, though good for society, is not an individual duty of every company. Making philanthropic donations is optional; making a positive contribution to the general common good of society, without denying or passing on responsibility for society's problems and challenges, is not. Companies must avoid being freeriders. If they want to be respected institutions in society, they must consider these dimensions as well.

These simple reflections remind us that companies are not only profit maximizers and that economic or decision-making models which overemphasize this objective at the expense of others encourage in business leaders an unhealthy view of the firm quite unlike the one a vibrant and dynamic society actually needs. ${ }^{14}$ From the 1980 s through the 2000 s, the preeminence of capital markets, investment banks and financial goals has been undisputed and firms have been seen almost exclusively as profit makers. Many of the excesses and crises that have occurred during this period have been in part a natural consequence of a warped view of the firm. A positive notion of the firm is not simply about avoiding scandals, but it can certainly help make them less likely. It also helps redefine the role of the public sector in the economy.

\subsection{Reframing the Role of Senior Managers}

A revised notion of the firm has implications for the functions and role of senior business leaders. In close parallelism with the notion of the firm as a profit maximizer, the role of senior business leaders, starting with the CEO, board members and members of the top management team, has been seen as being to make commitments to shareholders and stick to them. Some managers have gone even further, claiming that their job is to make shareholders wealthier. Yet wealth creation by a firm is the outcome of a process. If that process is not well designed and well managed, the outcome cannot be good, even if certain financial indicators say that the firm has made a profit in the short term. The task of senior managers is to make sure that the company they serve performs its basic function in society, as described above.

Business leaders must therefore take care of the context and process of wealth creation, as well as the final result. In other words, they must be process-driven; results will follow. ${ }^{15}$ If they are exclusively results-driven and show no concern for process or context, crisis will follow. The process that senior managers must look after is the process whereby: people are attracted to the organization and become involved in the firm's projects; goods and services that customers want to buy are designed, produced and delivered efficiently and economic value is created; the people in the organization are enabled and encouraged to learn; and the firm as a whole actively contributes to meeting society's needs.

This perspective does not ignore results, but it accepts that good performance is the outcome of many small decisions regarding people, customers, products, services, operations, marketing and many other dimensions. The chief executive's role is to ensure that people work efficiently

\footnotetext{
${ }^{14}$ Ghoshal and Bartlett (1997) made a serious attempt at rethinking the firm and the role of management. See also Hamel's recent effort (2007).

${ }^{15}$ See Ghoshal and Bartlett (1997).
} 
and effectively in such a way that employees feel proud of what they do, customers are satisfied with what the firm offers them (i.e., willing to pay for it above opportunity cost) and shareholders are pleased enough with the financial performance of their investment.

This basic notion of the role of senior business leaders has several implications. The first is that the main function of business leaders is to serve. Service is the key attribute in any profession worthy of its name and so also in the business world. A business leader who does not serve the company's people, customers and shareholders, as well as the wider society, is not a good professional. He may help the company make money in the short term, but he is unlikely to create an organization that is sustainable in the long term.

The service perspective in business leadership also calls into question the notion of charismatic leaders, not only in terms on the final results they may obtain but also in terms of the nature of their job. Great leaders help others succeed, generate trust around them, help other people get things done and encourage them to improve as they do it. What honors service-based leaders is not their individual performance, but the performance of the team as a whole over the years.

The service perspective also highlights the fact that the relevant time frame for senior business leaders in organizations is the long term, not the short term. While striving for the long term, a senior manager may fail in the short term and be fired. But there is a conviction that any good board of directors or CEO should have, namely that a great company is built over many years by the effort of many people. For such a project to succeed, senior managers must be fully committed to it. Reducing CEO tenure and hiring outsiders to fill the top jobs is neither the most coherent way to foster customer and employee loyalty nor the most effective way to build a great organization that lasts.

Lastly, a word about leaders as servants. There are many good theories about leadership, at least as many as there are bad ones. One of the good ones is that business leaders must lead by example. Many successful organizations that have passed the test of time demonstrate that good leaders are those who lead by example. Example consists of a mix of professionalism, fairness, virtue, courage, strength and generosity in thinking about and dealing with others. In summary, it does not mean putting other people ahead of oneself (this may not even be human), but putting other people and their interests and ambitions at least at the same level as oneself.

Through positive example, senior managers will become a force for change in society; and management, a profession for the good of other people and of organizations and society at large. More importantly, management will eventually not only be a respected profession, but one that attracts talented young people who want to have a significant positive impact on the lives of other people and society.

This idea of the role of business leaders, like the notion of the firm described above, clashes with the view that pervades many business theories and also many programs and courses taught at business schools. In some of these theories and programs the notion of individual success, finding one's opportunities, discovering the mechanisms of power and influence and planning one's next professional move come first. These may be legitimate aspirations, but they look selfish if taken as the only ones a good business leader should have. Just as a good surgeon is supposed to think not only about the money he will make in an operation but first and foremost about how he will restore the patient's health, a good business leader should not think first, or exclusively, of the material rewards of his job. A business leader's desire for 
rewards is legitimate but may become obscene if it overrides consideration of any other responsibility towards employees, customers, shareholders or society.

Business schools need to rethink both the notion of the firm and the role of business leaders in this perspective. The dominant paradigms today in many investment banks, public firms and entrepreneurial ventures is still the financial view of the firm and the opportunistic approach to business leadership. Business schools may not be directly responsible for actively promoting these views, but they may be to blame for having been too slow to propose more serious and more comprehensive views of what a firm is and what society expects from business leaders. It is time business school faculty realized how important this challenge is for the business world, for society and for the role and long-term success of business schools themselves.

\subsection{Problem Integration: The Value of Specialized Knowledge}

The firm, as a modern institution developed in the past century, was built around business functions such as purchasing, manufacturing, logistics, marketing and sales. Some firms obtained specific advantages by scaling up some of their divisions, so that what at that time were complex and inefficient functions could be made easier and cheaper by aggregating and coordinating them through managers. This allowed them to produce cheaper goods that many more people could afford to buy; it also made it possible to bring new discoveries and technologies to the mass market faster.

The sheer power of specialized business functions such as marketing, operations or finance is clear, but equally clearly, such specialization can also bring problems. The job of senior managers is not only to supervise but also to coordinate the specialized functions, so that the objectives of all the functions and units within the firm are compatible and the firm's overarching goal is achieved.

Over the past few decades many companies have grown in complexity. Some basic processes can still be managed and run in this organizational form based on specialized functions. Many others, however, require a more complex organizational design. Some firms, for example, work around projects or networks, rather than traditional manufacturing processes. Some undergo major organizational change. Others rely on sources of innovation that are interrelated with their customers' behavior or that are jointly developed with other companies. At the same time, firms face other challenges, such as building a more energy efficient model of manufacturing or developing a more efficient, more integrated organization, where the role of basic business functions is important but clearly insufficient. ${ }^{16}$

Unfortunately, business schools in general have been slow to react to some of these changes. Business programs and scholarship still tend to be based around business functions. There is nothing wrong with that, but there is something wrong when, in such courses, all the reflection, diagnosis and decisions surrounding business problems are approached exclusively from the perspective of the function, rather than of the company as a whole.

Moreover, this whole-company perspective is becoming increasingly important for senior managers. In the past, many business managers who were successful in running a unit, a function or a division were put in charge of larger or more complex units within the same firm.

\footnotetext{
${ }^{16}$ Martin (2007) has developed an important model on how to help business leaders think in an integrated way.
} 
Some rose to the challenge, while others failed, in part because they clung to their functional perspective (operations, marketing, finance or whatever) and tried to run the firm on that basis.

General management, as a profession, requires integration. Yet integration is something business schools tend not to be overly concerned about. Faculty find it complex and not very useful for their research agenda. Basically, there are three ways of tackling this problem. The first is a market-based approach which says that each professor should simply teach students the basic functions and the tools they need, on the assumption that if the students are clever enough, they will learn how to integrate them. This approach has obvious limitations.

The other two approaches are more positive. One is to change the curriculum and, instead of talking about functions such as marketing or operations, focus instead on customers or capital markets or people. Stanford, Yale, IMD and others have made considerable efforts in curriculum redesign, course development, case writing and faculty development. The second integrative approach, adopted by Harvard, IESE and other schools using the case method, is to learn how to analyze and make decisions to resolve business problems not only from the functional manager's point of view but from the whole company's point of view, taking into account the effects the decision will have on people and on other parts of the company and the impact it will have on the company's performance both in the short term and in the long term. Case studies are not descriptive illustrations or structured situations to which stylized models can be applied. They serve to prompt business leaders to think holistically about problems, solutions and decisions, and their impact on people, organizational units and the company as a whole, both short-term and long-term. Teaching integrated courses is an important step, but helping people think in an integrated way is a transformational experience that business schools should aim for.

The world today is facing new, complex and increasingly menacing problems. Some are technical, but most have to do with leadership. Business schools can and should make a contribution to the whole of society by helping it tackle some of the problems where they have proven knowledge and capabilities. Their faculty must learn how to address large social problems affecting business and society, such as education, welfare, pension reform, health care or cultural integration, and not only put forward theoretical alternatives but also managerial paradigms. This is a very unique contribution that business schools can make to society today and tomorrow by encouraging faculty members to work across disciplines and problems.

\subsection{A Framework for Leadership Development}

An indirect effect of the lack of integration of some areas of business education is the fact that there are not many coherent and comprehensive models of leadership development or management. ${ }^{17}$ Basically, schools put together packages of knowledge and skills and split them up among academic areas, which in the best of cases teach them with rigor and professionalism, but often without a clear framework for integrating them or using them to educate for leadership responsibilities.

Like integration and cross-disciplinary, cross-functional learning, leadership development is not only a complex process, but also one that many schools leave to market forces and student or faculty initiative.

\footnotetext{
${ }^{17}$ Hamel (2007) makes a very strong case for the need to reinvent management as we know it.
} 
Many schools have no shared view of what a senior manager or business leader is and should be able to do, or of how to educate for those capabilities. ${ }^{18}$ Again, comparison with a different profession, such as medicine, is illuminating. In medicine there is a set of knowledge that medical doctors must acquire and a set of practices that they must learn and follow. In business leadership the knowledge is reasonably well defined, but the process of using this knowledge or developing the skills and capabilities to effectively manage or lead an organization and its people is far from explicit.

The problem is that without a framework defining what a business leader should do, it is very difficult to design and deliver programs that will have a deep impact on the individuals who take part in them. Management is admittedly more complex than any other profession because it involves not only knowledge, but also capabilities and attitudes that have to do with working and interacting with other people who are free and have their own interests, values, duties and motivations. Nevertheless, the sheer complexity of defining and sharing a model of leadership development should not stop business schools from working hard to make headway in this extremely important area for companies and societies alike.

\subsection{Globalization}

Globalization is one of the major forces in the world, one that is deeply impacting the way companies are managed and operate. It is not a new phenomenon, as the world already experienced a significant process of globalization at the beginning of the twentieth century. ${ }^{19}$ Today, however, we are seeing new countries emerge into the world economy, opening up huge markets for existing multinational companies, while also creating multinationals of their own.

Companies of all sizes and in all industries have been trying to meet this challenge by expanding their international operations, setting up plants or sales offices in other countries, establishing joint ventures with foreign partners and off-shoring operations and research centers in emerging economies. This is certainly a new world for many companies; and all this has happened in such a short time.

Business schools have reacted to the changes in a variety of ways: by offering more courses on international business in their curricula and executive programs; by establishing alliances for student and faculty exchange; by organizing international trips; and by trying to attract more international faculty or students to their campuses.

Despite the variety of strategies and initiatives, discussions with business leaders from different industries and countries reveals a widespread feeling that business schools are not doing enough to help managers and firms cope with globalization. ${ }^{20}$ Managing and leading international companies has become an increasingly complex task in recent years and business leaders feel strong pressure to deliver in a more uncertain environment. They see that some business school faculty members are reluctant to move outside their area of knowledge and

\footnotetext{
${ }^{18}$ The Center for Creative Leadership has developed a very robust model of leadership development and learning that helps senior managers grow along several dimensions. In IESE's programs many faculty members share a model developed by the late Professor Juan A. Pérez-López, in which a distinction is made between executive capabilities, strategic capabilities and leadership capabilities. There is no single answer to this challenge, but more experiments are needed in order to advance in this very important area for firms and business schools.

${ }^{19}$ For a historical perspective, see Ferguson (2008) and James (2001).

${ }^{20}$ Ghemawat (2008) has explored and documented very well some of the problems that business schools face in adapting or reacting to globalization.
} 
expertise and do not actively address international issues in their courses and programs; that schools are not innovative enough in the area of international executive education and are not developing leading edge concepts and models to help managers understand and deal with the new realities; that there is a lack of basic knowledge on international business to be shared by companies and schools; that in their custom programs, schools are still embedded in their national culture and systems, while companies need to move as smoothly as possible across cultures and countries.

Obviously, there is no simple answer to this challenge. On the one hand, business schools are higher education institutions and their faculty are the most important pillar in their development. Without excellent faculty it is very difficult to get outstanding teaching and learning, or research with impact. Faculty development is expensive and time-consuming. Within this constraint, schools could more aggressively pursue strategies aimed at internationalizing faculty, staff and students; increase the number and impact of exchange students and faculty exchange programs; organize executive programs in cooperation with other schools on other continents; work with international firms, not only in student recruitment but also in executive education; develop teaching materials and courses with a strong international accent and content; make sure that international content is present in all required courses; and finally, implement mechanisms to ensure that class and professional discussions of international business take into account not only the dominant view on how to do things, but a range of possible action alternatives, depending on national environments.

Companies today have a unique obstacle to overcome in order to operate more effectively in our global world: the capacity of senior managers to understand differences across countries and exploit those differences to make firms better. This goal requires not only knowledge, but also a set of skills that can and must be taught and learned, and an understanding of human values and attitudes. It is the job of business schools not only to make sure that there is solid international content in their curricula, but also to help managers understand differences across countries and cultures and know how to act professionally in the context of such differences.

\subsection{Relevance}

As Khurana (2007) points out, since the 1970s most business schools have been trying to catch up with other university departments in terms of knowledge generation, methodological rigor and research impact. Publication in top academic journals has become the paradigm of excellence and scholarship. This effort has been very impressive in management and its various sub-areas, but it has had an unintended side effect: a significant proportion of management research is considered irrelevant to management practice. This does not sit well with the reason for which business schools were originally founded at the beginning of the $20^{\text {th }}$ century, namely to help improve the profession of management.

The question is not whether it is legitimate that some business schools should reduce the notion of scholarship to that particular type of research. The problem would be if a majority of business schools were to adopt this strategy. If they did, who would educate the business leaders of the future? Leadership development requires knowledge and research, but research on issues that are important to the business community; research that addresses the challenges business wants to address and the solutions it wants to provide. While statistical and other quantitative methods have given a stamp of rigor to some empirical studies, many of these studies offer no substantial ideas about how to improve the practice of management. So 
research is important and must be rigorous; but the world also needs research based on real data and management practice whose outcome could be useful to business. ${ }^{21}$

One answer to this question is that researchers must take a broader view when studying their special research questions and come up with more specific knowledge about problems and solutions for practicing managers. Otherwise, business schools will become more like economics or sociology departments and their identity and purpose will be in jeopardy.

On the other hand, leadership development and business education require good learning methodologies and excellent faculty, who help students develop the necessary skills, capabilities and attitudes. Unfortunately, some faculty see teaching as a necessary evil in order to survive in a business school. This is a very poor motivation for scholars who must not only serve scholarship through research but also through teaching, especially the teaching of management and business leadership, where the teaching and learning process is more complex than in most other academic areas.

Another telling observation in relation to the relevance of business school is that some of the most useful management ideas generated in recent decades, such as lean manufacturing, global supply chain management or high performance teams, appear to have emerged out of business practice and only later to have been redefined and generalized in business school research and teaching. Management practice evidently influences business school research, which is a good thing. Similarly, while modern corporate finance was instrumental in developing valuation methods for some financial instruments, financial innovation and the growth of financial institutions in the West, as well as the many deals around mergers, acquisitions, IPOs and other forms of financial advisory services, have been driven by bankers rather than scholars. The many theories about the working of capital markets, financial innovation or M\&A that have spread around the world have their roots in the advice and practice of investment banks rather than in academia. With the world immersed in a financial crisis, this is a great opportunity for business schools to make a stronger contribution. Yet many finance scholars still seem more interested in refining their already very sophisticated models than in shedding new light on how investment banks can make a better contribution to the business world and society.

Although many great schools are making exceptional efforts to be relevant and have a positive impact on students, firms and society, with the result that their students and alumni are extremely pleased with the educational experience they receive, the social function and reputation of business schools also depends on a majority of schools making an outstanding job of being both rigorous and relevant.

\subsection{Life-long Learning}

As a result of the explosion of diversity and complexity in all areas of knowledge, a significant part of the educational process becomes obsolete quicker now than in the past. This is obvious in scientific disciplines such as physics, biology or chemistry, but also in some social sciences such as economics. And it is already becoming apparent in business leadership and management. Certain basic frames and concepts are universally valid, but as leadership challenges evolve and new realities emerge, the specific capabilities needed in one context may not be right for another.

\footnotetext{
${ }^{21}$ It is intriguing that in some articles on what makes research interesting, the impact on the real world is not a reference. See, for instance, Bartunek, Rynes and Ireland (2006).
} 
The speed of change in the business world and the accelerated pace of innovation creates new opportunities for leadership development. Yet business schools seem too intent on merely refining their existing undergraduate or graduate education model. The Bologna reform across the EU is a case in point. The Bologna agreement will have a profound impact on the way students across Europe learn, get their degrees, acquire a different cultural perception of individuals and countries and pursue their education in a more standardized way across Europe. But it does not address the fundamental problem in a modern society: how do educated adults keep learning? How can universities help them keep their jobs, get a new job or develop new professional projects? And in the case of business schools, what do they offer their graduates in the way of continuous learning opportunities? Are those opportunities as well designed and structured as the schools' other programs and courses?

Continuous education and learning is clearly a big challenge in our society. But it is also a great opportunity for business schools, as many graduates are eager to keep learning and developing new capabilities, or to embark on a second or third career. At the same time, companies and society at large need business schools to keep contributing to the development of managers' knowledge and capabilities.

To meet this challenge schools must adopt a new strategy, more open to considering classic undergraduate and graduate programs as initial steps in an ongoing professional development process. They also need to think of executive education programs not as a portfolio of disparate areas and topics, but as a means of meeting the new educational needs that individuals and companies may have.

Continuous education has always been an important yet unfulfilled basic educational need. In today's knowledge society, given current demographic trends and longer life expectancy, this need is more pressing than ever and business schools should take it seriously.

\subsection{Organizational Structure}

Business schools are relatively young institutions. Some have acquired a worldwide reputation in a very short time, with strong faculty, excellent students and alumni, outstanding programs and a formidable brand name. These success factors have not come together by chance. Behind these successes lies excellent leadership. The professional approach to institutional management adopted by most business schools is among the best in professional education and is recognized as such across universities.

In some cases, certain other factors have helped: the vision of the founders; the focus on helping educate business leaders and so knowing more about management and real firms; the need to compete for faculty and students in a highly competitive market; the need to pay close attention to students' development and the expectations of corporate clients; or the influence of alumni.

Business schools still have room for improvement, however. Areas that business school leaders and faculty need to think about include: the impact schools have on students and corporate clients; the ability of faculty to improve existing approaches and develop and try out new ones; professionalism in the management of internal operations, alumni offices, technology, staffing needs and customer service; the development of new courses for alumni; the agility and speed to make changes in response to new market challenges.

For some leading United States business schools a growing endowment has meant an increasing source of revenue for the school. But this may not be true in the future and is a 
source of deep financial pain today. For other schools, lack of an endowment has meant having to set up new programs to obtain the funding required to be financially viable. We all need to think about models that will make our institutions more viable in the long term. Gifts and endowments will help, but learning how to manage a business school in a downturn and, more importantly, helping faculty and staff adapt to the new circumstances are new challenges that will have to be faced.

\section{Some Final Reflections}

Management has become a very relevant and decisive profession in our societies and a driving force of economic growth in the twentieth century. Business schools have been very successful institutions over the past decades. Most of them have had a very positive impact on individuals, firms and society at large, both in the Western world and in emerging countries and regions.

The question is how business schools will face the new realities and demands of the twenty-first century, which are radically different from those of the early twentieth century, when the first business schools came into being in the United States, or the 1950s and '60s, when many more started in Europe, the United States and other parts of the world.

Today's business schools face daunting challenges. The reason is that their educational and research agenda is determined not only by their faculty, but also by companies and society. The identity and reputation of business schools depend very much on the service they provide to their constituencies. As stated earlier, a very important contribution they can make to the business world is to redefine the notion of the firm, the meaning of the management profession, the role of senior managers, the service orientation that professional managers must have, and the unique mission of companies in society, beyond generating economic value.

The current crisis of the capitalist system goes beyond the crisis of management and leadership, but it certainly has some roots in the crisis of the banking system and the poor leadership in many banks and other non-financial firms. The problem in many of those firms was not a lack of knowledge or technical skills, but a lack of the basic ingredients for leading organizations: a mission, a commitment to professionalism and service, a sense of justice and an aspiration to do good in society through the business world. These are complex and demanding needs that have an impact on business schools and how their mission is perceived by the business world and society. Business schools alone cannot solve these problems, but they and their faculties have the potential to help address many of them. Though the challenges are huge, the need for excellent business schools is even clearer today than it was roughly a century ago, when the first schools were founded. The opportunities for great educational programs and relevant research are bigger than ever. 


\section{References}

Andreu, R. (2009), "Knowledge, learning and competitive advantage: Implications for the management profession," Conference on Humanizing the firm and the management profession, IESE, Barcelona.

Barnard, C. (1938), “The functions of the executive," Harvard University Press, Boston.

Bartunek,J.M., Rynes, S.L, and Ireland, R.D. (2006), "What makes management research interesting and why does it matter?," Academy of Management Journal, 49(1), pp. 9-15.

Collins, J. and 0'Toole, J. (2005), "How business schools lost their way," Harvard Business Review, May-June.

Collins, J. and Porras, J. (1996), "Building your company's vision," Harvard Business Review, September-October, pp. 65-77.

Chandler, A. (1977), “The visible hand,” Harvard University Press, Cambridge, MA.

Chandler, A. (1990), Scale and scope, Harvard University Press, Cambridge, MA.

Drucker, P. (1974), “Management: Tasks, Responsibilities and Practices,” Harper \& Row, New York.

Ferguson, N. (2008), “The ascent of money,” Penguin, New York.

Ferraro, F., Pfeffer, J., and Sutton, R.I. (2005), "Economics language and assumptions: How theories can become self-fulfilling," Academy of Managemet Review, 30(1), pp. 8-24.

Holtom, B.C. and Inderrieden, E.J. (2006), "Examining the value added by graduate management education," GMAC Research Reports, RR-06-16.

Ghemawat, P. (2007), “Redefining global strategy,” Harvard Business School Press, Boston.

Ghemawat, P. (2008), "The globalization of business education: Through the lens of semiglobalization," Journal of Management Development, 4, pp. 391-414.

Ghoshal, S. (2005), "Bad management theories are destroying good management practices," Academy of Management Learning and Education, 4(1), pp. 75-91.

Ghoshal, S. and Bartlett, C.A. (1997), "The individualized corporation," HarperBusiness, New York.

Ghoshal, S. and Moran, P. (1996), "Bad for practice: A critique of transaction cost theory," Academy of Management Review, 21(1), 13-47.

Khurana, R. (2007), “From higher aims to hired hands," Princeton University Press, Princeton, NJ

Hamel, G. (2007), “The future of management,” Harvard Business School Press, Boston.

James, H. (2001), "The end of globalization: Lessons from the Great Depression," Harvard University Press, Cambridge, MA. 
Lorange, P. (2008), “Thought leadership means business,- Cambridge University Press, Cambridge.

Martin, R. (2007), “The opposable mind,” Harvard Business School Press, Boston.

Minztberg, H. (2004), “Managers, not MBAs,” Pearson Education, London.

Pfeffer, J. and Fong, C.T. (2002), "The end of business schools? Less success than meets the eye," Academy of Management Learning and Education, 1, pp. 78-95.

Roberts, J. (2004), “The modern firm,” Oxford University Press, Oxford.

Rosanas, J.M. (2008), "Beyond economic criteria: A humanistic approach to organizational survival," Journal of Business Ethics, pp. 345-369.

Selznick, P. (1957), Leadership in administration, University of California Press, Berkeley and LA.

Thomas, H. (2007), "An analysis of the environmental and competitive dynamics of management education,” Journal of Management Development, 26(1), pp. 9-21. 